Hussein BOUgSiaA

LUCYNA KOPCIEWICZ

ORCID 0000-0003-0888-7665

Uniwersytet Gdański

\title{
IPAD JAKO NARZĘDZIE EDUKACYJNEJ ZMIANY? PORÓWNAWCZE BADANIE WDROŻENIA PROJEKTU EDUKACYJNEGO W LIBII I POLSCE
}

\begin{abstract}
Bougsiaa Hussein, Kopciewicz Lucyna, iPad jako narzędzie edukacyjnej zmiany? Porównawcze badanie wdrożenia projektu edukacyjnego w Libii i Polsce [Is the iPad a Tool for Educational Change? International Comparative Study on iPads' Implementation at Libyan and Polish Schools]. Studia Edukacyjne nr 52, 2019, Poznań 2019, pp. 192-211. Adam Mickiewicz University Press. ISSN 1233-6688. DOI: $10.14746 /$ se.2019.52.13
\end{abstract}

This comparative small-scale (Libyan and Polish sample) qualitative study investigates two educational models of iPads' implementation and integration with the overall pedagogical objectives in early education in Libya and Poland. The basic methodological frame was video-ethnography supplemented by semi-structured interviews with parents, teachers and children. The questions asked were designed to recognize how technology might fit within the school's overall vision. The results indicate that each technology initiative can be potentially transformative for schools, teachers and students. The iPad as an open educational tool encourages a student-centered model of learning, whereas teachers predominantly use frontal teaching methods. Furthermore, the teachers in the two countries have considerably different perceptions and expectations regarding the role and outcome of mobile technology.

Key words: Mobile Technologies, school, change, early education in Poland and in Libya, iPad

W ostatnich latach szkoły na całym świecie są konfrontowane z wyzwaniami płynącymi ze świata współczesnych technologii, które coraz częściej stają się narzędziami szkolnego uczenia się ${ }^{1}$. Wydaje się, że presja na włącza-

${ }^{1}$ Artykuł powstał $\mathrm{w}$ ramach projektu badawczego finansowanego przez Narodowe Centrum Nauki 2015/19/B/HS6/02218: Uczenie się wspomagane technologiami mobilnymi 
nie technologii mobilnych do edukacji szkolnej powinna być wprost proporcjonalna do zwiększającej się dostępności urządzeń mobilnych w danym społeczeństwie. Jednak światowa literatura przedmiotu nie potwierdza wprost takiej zależności. Dość dobrze dokumentuje inny proces - implementacji nowoczesnych technologii w krajach rozwijających się lub o umiarkowanym stopniu rozwoju społeczno-ekonomicznego ${ }^{2}$.

Technologie mobilne wkroczyły do wielu szkół na całym świecie. Obecność tych rozwiązań jest traktowana przez wielu badaczy edukacyjnych jako oczywisty krok modernizacyjny, który powinien skutkować poprawą wyników nauczania ${ }^{3}$ Z Z drugiej strony, rozwiązania takie są krytykowane za silne podporządkowanie szkół globalnemu kapitalizmowi i narzucenie szkołom jego standaryzującej logiki za pośrednictwem nowoczesnych narzędzi kształcenia ${ }^{4}$. Literatura przedmiotu nie przekonuje dostatecznie wyraźnie, czy technologie mobilne mają wpływ na poprawę efektywności nauczania $\mathrm{w}$ porównaniu $\mathrm{z}$ nauczaniem tradycyjnym ${ }^{5}$. Z drugiej strony wiele prac badawczych przekonuje, że nauczyciele i uczniowie cenią sobie nowe rozwiązania technologiczne w edukacji. Nauczyciele wskazują, że technologie mobilne otwierają nowe możliwości uczenia się, oferując szeroką gamę nowych metod dydaktycznych, sposobów tworzenia wiedzy i jej prezentacji. Rezultaty tych badań ukazują, że mobilne technologie tworzą nowe możliwości w zakresie uczenia się wykraczającego poza tradycyjny wzorzec aktywności klasowej, kierowanej przez nauczyciela ${ }^{6}$. W literaturze przedmiotu eksponowane jest edukacyjne znaczenie mobilności i kontekstu, istotnych z punktu widzenia nauczania i uczenia się wzbogaconego technologicznie ${ }^{7}$. Wielu badaczy technologii mobilnych przekonuje, że są one wyzwaniem dla transmisyjnego modelu nauczania, sprzyjają zindywidualizowanemu uczeniu się oraz komunikacji i współpracy zachodzącej

w szkołach pomorskich. Krytyczne pytania o rozwój „kompetencji XXI wieku” oraz genderową inkluzję w szkolnych modelach BYOD/BYOT oraz OPD.

2 J. Traxler, Education and the Impact of Mobiles and Mobility: An Introduction to Mobiles in our Societies, [w:] Medienbildung in neuen Kulturraumen: Die deutchsprachige und britische Diskussion, red. B. Bachmair, Wiesbaden 2010.

3 J. Traxler, Will Student Devices Deliver Innovation, Inclusion \& Transformation? Journal of the Research Center for Educational Technology at Kent State University, 2010, 6, 1, s. 3-15.

${ }^{4}$ T. Nowicki, Technologiczne transpozycje podmiotu i pracy, Teraźniejszość - Człowiek - Edukacja, 2016, 19, 2(74), s. 53-66.

${ }^{5}$ M. Pegrum, Mobile learning. Languages, literacies, cultures, New York 2014.

${ }^{6}$ A. Gasparini, A.L., Culén, Children's Journey with iPads in the Classroom. Opportunities and Challenges when Designing and Developing with Kids @ School, [w:] Interaction Design for Children Conference (IDC 2011), Michigan 2011.

${ }^{7}$ J. Traxler, Mobile learning. Starting in the right place, going in the right direction? [w:] Innovations in Mobile Educational Technologies and Applications, red. D. Parsons, Hershey 2013. 
między osobami uczącymi się ${ }^{8}$. Badanie omówione w tym artykule wpisuje się również $\mathrm{w}$ ten nurt teoretyczny. Zamierzamy przedstawić dwa projekty wdrożenia technologii mobilnych do szkół i ich edukacyjne rezultaty. Czynimy to jednak w dość ryzykownej perspektywie międzynarodowych porównań z zakresu wczesnej edukacji.

\section{Technologie mobilne we wczesnej edukacji: poza dyskursem zagrożonego lub wyzwolonego dziecka}

Warto zarysować w tym miejscu ramy teoretyczne, w których osadzone są nasze badania. Pojawienie się urządzeń mobilnych owocowało licznymi dyskusjami w obszarze nauk społecznych i humanistycznych na temat zmian istoty i charakteru społecznych relacji, wzorów kultury, uczenia się i socjalizacji oraz pojawienia się nowych wzorów tożsamości we współczesnym społeczeństwie informacyjnym ${ }^{9}$.

Analizując kulturowe, społeczne i edukacyjne funkcjonowanie współczesnych technologii informacyjno-komunikacyjnych, niejednokrotnie przekonywaliśmy się, że wkraczamy na wysoce konfliktogenny teren. Przegląd współczesnej literatury przedmiotu przekonuje niezbicie, iż teoretycy i badacze współczesnej kultury, społeczeństwa i edukacji zgadzają się, iż owe technologie zajmują istotne miejsce $w$ każdej analizowanej sferze. I na tym stwierdzeniu, w zasadzie, kończy się teoretyczny konsensus. Cała obszerna reszta to rozległe obszary sporu o: status współczesnych technologii, sposób ich badania i opisywania, ich ocenę. Istotną rolę w owych sporach odgrywa język, a konkretnie binarne opozycje, za pomocą których porządek technologiczny przeciwstawia się porządkowi społecznemu, technologię - naturze, sztuczność - autentyczności, czynnik ludzki - nieludzkiemu, czy materialność - duchowości ${ }^{10}$. Myślenie uwikłane w opozycjonowanie wprowadza jednak szereg fałszywych sposobów widzenia związków technologii z tym co społeczne. Sprowadzają się one, najogólniej rzecz ujmując, do dwóch przeciwstawnych pytań: czy człowiek posługuje się technologią (w procesach jej tworzenia, używania i kontrolowania) czy raczej technologia "posługuje” się ludźmi, narzucając im nowe ramy odniesienia, w których, czy tego chcą czy nie, muszą się odnaleźć. Ponieważ rozwój technologii informacyjnych jest ściśle związany z dyskursem postępu, dlatego wielu badaczy zakłada deterministycznie, że technologie są sprawcze same w sobie i wyzwalają -

\footnotetext{
${ }^{8}$ S. Dylak, Architektura wiedzy w szkole, Warszawa 2013.

9 A. Dingli, D. Seychel, The New Digital Natives: Cutting the Chord, Berlin - Heidelberg 2015.

${ }^{10}$ P. Nosol, Technologia $i$ sport, Gdańsk 2014.
} 
w natychmiastowy sposób, przez sam fakt ich istnienia - jakiś rewolucyjny, emancypacyjny, czy demokratyczny potencjał: automatycznie wyzwalają uczenie się, kreatywność i same w sobie sprzyjają rozwojowi, zwłaszcza najmłodszych pokoleń.

Konkurencyjnym paradygmatem jest antydeterminizm, którego punktem wyjścia są fenomenologia i społeczny konstruktywizm. Istotą tego paradygmatu jest założenie o wytwarzaniu kultury - znaczeń i praktyk w codziennym ludzkim życiu ${ }^{11}$. Zatem, technologie mobilne mogą sprzyjać dziecięcemu rozwojowi, o ile będą one używane w kontekstach, które będą temu rozwojowi sprzyjać - będą nastawione na twórczą partycypację dzieci w kulturze. A to zadanie ma mniejszy związek z samą technologią, a większy ze stosunkami społecznymi, czy relacjami edukacyjnymi, konstruowanymi wokół technologii.

Trzeba też zwrócić uwagę na dyskurs technologii w kontekście aksjologicznym, czyli na sposoby wartościowania zmian kulturowo-społecznych zachodzących w związku z technologiami. W obrębie tej formacji dyskursywnej mamy do czynienia ze stanowiskami technofobicznymi oraz technoentuzjastycznymi. Negatywne bądź pozytywne postrzeganie technologii dotyczy kilku wyraźnie wyodrębnionych aspektów: oceny kierunku rozwoju cywilizacyjnego, wpływu technologii na ludzkie zdolności oraz stopnia rozumienia przez jednostki otaczających je procesów technospołecznych.

Sposoby wartościowania technologii mobilnych w kontekście społecznym czy edukacyjnym ze szczególną ostrością dotykają kwestii dzieciństwa. Przestrzeń współczesnych badań dzieciństwa w związku z mobilnymi technologiami zdominowana jest dziś przez dwie niezbyt fortunne orientacje teoretyczne: badania utrzymane $\mathrm{w}$ alarmistycznym duchu, amplifikujące model „zagrożonego dzieciństwa” i badania apriorycznie celebrujące wzór wyemancypowanych, kompetentnych cyberkids ${ }^{12}$. Obie orientacje pozbawiają badaczy szansy na pełne poznanie niewątpliwych potencjałów kultury cyfrowej, ale też całego szeregu zastrzeżeń i ograniczeń związanych z dziecięcą partycypacją. Zdaniem Davida Buckinghama, błędem teorii technofobicznych i technoentuzjastycznych jest założenie, że współczesna technologia sama w sobie jest sprawcza i wywołuje nieuchronne - opresyjne lub wyzwolicielskie - zmiany w następstwie jej upowszechnienia ${ }^{13}$. Innym nieporozumieniem jest, zdaniem autora, przywiązanie do romantycznej 2007

${ }^{11}$ A.H. Caron, L. Caronia, Moving cultures. Mobile communication in everyday life, Montreal

${ }_{12}$ D. Buckingham, Beyond technology: children's learning in the age of digital culture, Cambridge 2007.

${ }^{13}$ D. Buckingham, Nowe media - nowe postaci dzieciństwa? Zmieniajace się środowisko kulturowe dzieci werze technologii cyfrowej, [w:] Wprowadzenie do badań nad dzieciństwem, red. M.J. Kehily, Kraków, 2008, s. 156. 
koncepcji dzieciństwa w wersjach: pesymistycznej (dziecko niewinne, bezbronne, wymagające troski i ochrony) lub optymistycznej (dziecko kreatywne, naturalnie innowacyjne i kompetentne). Nałożenie się obu tych nieporozumień sprawia, że dzieci w kontakcie z kulturą cyfrową definiowane są esencjalistycznie jako „obcy", posiadający odrębne "cechy gatunkowe" (tak też należy tłumaczyć wysiłki badaczy do opisania specyfiki kolejnych fal pokoleń cyfrowych). Tymczasem, zdaniem Buckinghama, nie można rozpatrywać idei "sprawczości technologii” samej w sobie, odrzucając kontekst jej wykorzystania i abstrahując od konkretnych praktyk jej używania i miejsc społecznych, w których owa technologia się pojawia.

\section{Cel badań}

Istotą naszych badań, których wyniki przedstawione zostaną w niniejszym tekście, jest porównanie procesów implementacji technologii mobilnych w dwóch szkołach podstawowych - w Polsce i Libii. Nasz wybór padł na kraje o konserwatywnej kulturze edukacyjnej. Nie chodzi nam jednak o badanie efektywności kształcenia, jego poprawy bądź braku takiego efektu w kontekście mobilnych technologii w edukacji. Naszym celem jest przede wszystkim zbadanie ewentualnych zmian $w$ zakresie kultury edukacyjnej, zwłaszcza w wymiarach: współpracy szkoły z rodzicami, ewentualnych zmian w praktykach uczenia się dzieci oraz komunikacji między nauczycielami i uczniami.

\section{Metody badań}

Projekt badań został pomyślany jako jakościowe studium empiryczne, którego bazą była wideoetnografia ${ }^{14}$ (zapis wybranych zajęć lekcyjnych), uzupełniona wywiadami z nauczycielami, rozmowami z dziećmi, z dyrektorami szkół i rodzicami. W Libii badania przeprowadzono w 2015 roku, a w Polsce - w 2016, obejmując w każdej szkole jeden rok nauki szkolnej. Technologie mobilne w libijskich szkołach pojawiły się już w 2010 roku. Jednak projekt ten został przerwany przez wybuch rewolucji w 2011 roku. W roku 2014 powrócono do jego realizacji, choć w dalszym ciągu pojawiają się perturbacje i krótkie przerwy w związku z utrzymującymi się niepokojami społecznymi. W przypadku szkoły polskiej technologie mobilne pojawiły się w roku szkolnym 2015/2016 i dane pochodzą z pierwszego etapu ich wdrażania.

${ }^{14}$ S.J. Derry i in., Conducting Video Research in the Learning Sciences: Guidance on Selection, Analysis, Technology, and Ethics, Journal of the Learning Sciences, 2010, 19, 1, s. 3-53. 
W literaturze edukacyjnej brak międzynarodowych badań porównawczych, które były wykonane z wykorzystaniem dokładnie tego samego podejścia metodologicznego i dotyczyły tej samej technologii. Jak wskazuje Pegrum, należy zrozumieć, jak identyczne rozwiązania technologiczne "pracują" w różnych środowiskach szkolnych, jakie zmiany w ekologii klasy szkolnej wywołuje ich pojawienie się, jakie oczekiwania edukacyjne są pokładane w nowoczesnych technologiach, czy szkoła $\mathrm{z}$ technologiami mobilnymi wypracowuje efekty, których nie obserwowano przed ich wprowadzeniem ${ }^{15}$.

Na potrzeby badań zgromadzono duży korpus danych empirycznych: około 40 godzin materiału wideo z zapisem przebiegu zajęć szkolnych w Polsce i Libii, co pozwoliło na prześledzenie sfery praktyk związanych z technologiami mobilnymi w badanych szkołach. Interpretacje z tej części badań zostały osadzone $\mathrm{w}$ danych kontekstowych, które pochodziły $\mathrm{z}$ semistrukturyzowanych wywiadów z uczniami $(n=57)$, nauczycielami $(n=10)$ i rodzicami $(n=42)$ w obu krajach.

W przypadku danych wizualnych poszukiwaliśmy powtarzających się wzorów aktywności, typowych praktyk, najczęstszych aktywności uczniowskich i nauczycielskich pojawiających się podczas lekcji. W każdym kraju materiał wideo analizowany był odrębnie i kodowany. Następnie kody te zostały przejrzane i stworzyły mapę obserwowalnych praktyk uczenia się i nauczania w związku z technologami mobilnymi.

Podobna procedura została zastosowana w przypadku danych narracyjnych. Materiał pochodzący z wywiadów był kilkakrotnie przeczytany, a następnie poddany procedurze kodowania - wyłoniono z niego wiodące tematy, powtarzające się motywy, na przykład sposoby widzenia wpływu urządzeń mobilnych na szkolną aktywność dzieci czy oceniania edukacyjnych potencjałów mobilnych technologii. Materiał narracyjny był analizowany odrębnie w obu krajach.

Kolejnym krokiem było porównanie przestrzeni wynikowych w obu krajach oraz określenie występujących podobieństw i różnic.

W materiale empirycznym poszukiwaliśmy odpowiedzi na pytanie dotyczące sposobów rozumienia edukacyjnej roli technologii mobilnych, które pojawiły się w przestani badanych klas szkolnych, ale też staraliśmy się określić, na czym polegają ewentualne zmiany w edukacyjnym polu w związku z pojawieniem się $w$ nim nowych, sprawczych aktorów. Staraliśmy się również wyłonić niezmienne aspekty kultury edukacyjnej oraz aspekty, które zmieniły się najbardziej dzięki pojawieniu się technologii mobilnych w szkołach. Zagadnieniem o istotnym znaczeniu jest perspektywa rodziców, którzy oceniają rozwojowy potencjał nowych technologii w edukacji.

${ }^{15}$ M. Pegrum, Mobile learning. 
Badanie oparto na małej próbie i jego wyników nie sposób uogólniać. Niewielka skala badania rzutuje też na możliwości analizy, interpretacji i prezentacji zgromadzonego materiału badawczego. W niniejszym artykule zostanie przedstawiony pogłębiony opis wyników, zawierający „miary jakościowe”. Dane ilościowe zostaną zastosowane jedynie w części poświęconej projektowaniu edukacyjnemu.

\section{Kontekst badań: kultura edukacyjna w Libii i w Polsce}

Szkoły podstawowe w Libii są sześcioklasowe, bez wyraźnie wyodrębnionego etapu wczesnej edukacji. Naukę szkolną rozpoczynają dzieci sześcioletnie. Libijski system szkolny odzwierciedla system wartości społeczeństwa, naznaczonego licznymi hierarchizacjami i różnicami statusów. Dzieci są traktowane jako najsłabszy element libijskiego systemu edukacyjnego. Wymaga się od nich bezwzględnego posłuszeństwa, umiejętności zachowania dyscypliny, gotowości do wykonywania poleceń dorosłych, niekwestionowania tych poleceń i nieokazywania inicjatywy w obecności dorosłych. Kary fizyczne - bicie po głowie lub rękach - należą do dopuszczalnego repertuaru środków wychowawczych w szkołach ${ }^{16}$. Dzieci uczą się z podręczników jako głównego źródła wiedzy. Wiedza podręcznikowa jest uzupełniana przez opowiadania i wyjaśnienia nauczyciela. Rodzice traktują szkołę jako sprzymierzeńca w wychowaniu i nauczaniu. Szanują nauczycieli, bardzo im ufają i aprobują ich działania. Być może takie podejście jest spowodowane z jednej strony chęcią zapewnienia dzieciom wszystkiego co niezbędne, a z drugiej nieznajomością potrzeb dzieci i specyfiki ich rozwoju poznawczego. $Z$ tego względu nauczyciele otrzymują olbrzymi kredyt zaufania i szacunku jako ci, którzy wiedzą czego dziecko potrzebuje i wiedzą, jak tym potrzebom sprostać $^{17}$. Publiczne krytykowanie nauczycieli przez rodziców należy do zachowań absolutnie marginalnych.

Wczesna edukacja w Polsce jest pozornie najbardziej liberalnym etapem kształcenia. Naukę na tym etapie rozpoczynają dzieci 6- lub 7-letnie. Pozorny liberalizm jest rezultatem kulturowego założenia, zgodnie z którym wczesna edukacja jest jeszcze „niepoważną” fazą szkolnej edukacji, dlatego może być traktowana protekcjonalnie i pobłażliwie. Jak przekonują polskie badania poświęcone wczesnej edukacji, ten etap jest też definiowany jako „niewin-

${ }^{16}$ N. Clark, Education in Libya, World Education News and Reviews, 2004, 17(4), http:/ / www.wes.org/eWENR/04July/Practical.htm; [dostęp: 28.07.2017].

${ }_{17}$ A. Hamdy, ICT in education in Libya. Libya Country Report, http://www.infodev.org/ en/Document.412.pdf [dostęp: 23 czerwca 2017]. 
ny", wymagający jedynie dobrej atmosfery w klasie, nauczycielki, która kocha dzieci oraz pewnego stopnia zdyscyplinowania "maluszków”"18. Taki klimat edukacji sprzyja jednak bardzo wyraźnie marginalizacji dzieci w sferze udziału w procesach wytwarzania wiedzy i interpretowania życia społecznego, ucząc je, że nie one mają tu coś do powiedzenia, i wćwicza je w podtrzymywanie reguł społecznych, w których jedni marginalizują drugich. Źródłem wiarygodnej wiedzy o świecie są jedynie podręcznik i nauczyciel ${ }^{19}$.

Rodzice są bardzo krytycznie nastawieni wobec szkoły w Polsce, śledzą poczynania nauczycieli. Jednak nie podejmują bezpośrednich konfrontacji w nauczycielami czy dyrektorami szkól, preferując postawy obojętności i niezaangażowania („nie słucham szkoły, bo jest głupia”). Część rodziców aktywnie współpracuje z nauczycielami, ale też zdarzają się rodzice bardzo destrukcyjni - z punktu widzenia szkoły - którzy okazują niezadowolenie lub są permanentnymi krytykantami. Jak wskazują badania, nauczyciele obawiają się rodziców, ich reakcji i interwencji w szkole ${ }^{20}$.

\section{Wyniki badań}

\section{Projekt „iPad w szkole": procedury decyzyjne, motywacje i oczekiwania}

W dalszej części artykułu zostaną przedstawione wyniki badań dotyczące projektu wdrożenia technologii mobilnych w szkołach w Libii i w Polsce. Projekty te dotyczyły całej społeczności badanych szkół podstawowych. My jednak koncentrujemy się na mniejszym obszarze, to znaczy na wczesnej edukacji, a dokładniej - na rocznych badaniach przeprowadzonych w jednym oddziale klasowym w każdej ze szkół. Najpierw jednak przedstawimy okoliczności, w jakich iPady pojawiły się w poszczególnych szkołach.

iPady pojawiły się w szkołach w Trypolisie (stolicy kraju) z inicjatywy jednej z firm libijskiego sektora naftowego. Do projektu zakwalifikowano wszystkie szkoły, które zgłosiły chęć udziału w projekcie innowacji dydaktycznych. Każda szkoła otrzymała średnio 100 tabletów. iPady - na życzenie

${ }^{18}$ D. Klus-Stańska, Nauczanie początkowe jako wczesny trening do marginalizacji. Kontrowersyjność społecznej wiedzy szkolnej, Forum Oświatowe, 2011, 1(44), s. 5-26.

${ }^{19}$ D. Klus-Stańska, Poza kulturę nadzoru : eksperymentowanie w szkole i ze szkoła : z profesor Dorota Klus-Stańska rozmawia mgr Sylwester Zielka, Ars Educandi, 2010, 7, s. 149-168.

${ }^{20}$ M. Winiarski, Relacje rodzina - szkoła w perspektywie wspótpracy, [w:] Pedagogika społeczna wobec zagrożeń człowieka i idei sprawiedliwości społecznej, red. W. Danilewicz, W. Theiss, Warszawa 2014, s. 246-271; M. Mendyk, Wspótpraca z rodzicami z perspektywy nauczycieli edukacji wczesnoszkolnej - raport z badań, [w:] Codzienność szkoty - nauczyciel, red. J.M. Łukasik, I. Nowosad, M.J. Szymański, Kraków 2014, s. 199-210. 
dyrektorów szkół - zostały wdrożone na lekcjach ze wszystkich przedmiotów nauczania (czyli: matematyce, języku arabskim, języku angielskim, zajęciach społeczno-przyrodniczych, religii, sztuce i muzyce), poza wychowaniem fizycznym. Zespoły dyrekcyjne bardzo wyraźnie sformułowały swoje oczekiwania względem projektu. Chodziło o edukacyjną zmianę, ale realizowaną powoli.

Zgodnie z założeniami, pierwszym posunięciem zespołu projektowego (koordynatorów oraz wolontariuszy - studentów ICT) był kontakt z rodzicami uczennic i uczniów, bowiem chodziło o tworzenie zrębów pewnej kultury edukacyjnej w środowisku domowym. Zespół obawiał się nieprzychylnych reakcji rodziców, ponieważ w niektórych krajach arabskich właśnie rodzice stanowią bardzo aktywną grupę zwalczającą obecność "zbyt nowoczesnych" rozwiązań w nauczaniu. W przypadku rodziców libijskich większość bardzo przychylnie odniosła się do pomysłu wprowadzenia iPadów do szkół, ale pewne wątpliwości budziła możliwość wypożyczania sprzętu do domu po zajęciach szkolnych $\mathrm{w}$ celu przedłużenia czasu edukacji wspomaganej technologią mobilną. Rodzice $\mathrm{w}$ rodzinach $\mathrm{z}$ kilkorgiem dzieci bardzo chętnie korzystali z tej możliwości, widząc w niej szansę na szybsze uczenie się dzieci najmłodszych (w grupie, od dzieci starszych), co byłoby zdecydowanie pomocne $w$ perspektywie ich późniejszych szkolnych sukcesów. Opcja ta przypadła do gustu szczególnie matkom, zwalniając je z konieczności organizowania czasu wolnego dzieci. Obowiązek ten przejmowało dziecko przynoszące ze szkoły iPada. Bogatsze rodziny z Trypolisu, mające nie więcej niż trójkę dzieci (w Libii rodzina taka jest uznawana za małą), wyrażały pewien opór wobec projektu, nie deklarując zainteresowania wypożyczeniem sprzętu i kontynuacją nauki $\mathrm{w}$ domu. Utożsamiały bowiem dobrą edukację z kontaktem z profesjonalnym nauczycielem, którego zatrudnia się do nauki domowej, chcąc uzupełnić edukacyjne działanie szkoły.

W badanej szkole w Polsce iPady pojawiły się jako następstwo decyzji dyrekcji, która uczestniczyła w szkoleniu przygotowanym przez Apple dla nauczycieli i dyrektorów szkół, podczas którego zaprezentowane zostały możliwości edukacyjnego wykorzystania tabletów wraz z ofertą ich zakupu. Dyrekcja szkoły podjęła olbrzymie ryzyko „wypłynięcia na głęboką wodę", oczekując, że pierwsza w regionie pracowania edukacji mobilnej zapewni szkole miano edukacyjnego lidera i umocni jej pozycję na edukacyjnym rynku. Zespół dyrekcyjny spodziewał się również pewnej poprawy wyników nauczania. Ponieważ mobilna pracownia (zakupiono 28 tabletów) miała służyć całej szkolnej społeczności, dlatego iPady wykorzystywane były tylko na wybranych lekcjach przez niektórych nauczycieli. Uczniowie nie mogli wypożyczyć urządzeń do domu, ani korzystać z własnych tabletów w szkole. 
Rodzice uczniów odnieśli się raczej sceptycznie do obecności iPadów w nauczaniu. Niektórzy bardzo ostro oponowali, nie zgadzając się, by „dzieci zostały królikami doświadczalnymi”. Kilku rodziców nie zgodziło się, by ich dzieci korzystały z urządzeń na lekcjach, powołując się na przekonania religijne („,iPad jest narzędziem szatana”).

Dość poważną barierą we wdrożeniu tego projektu okazali się też sami nauczyciele. Oni również nie byli entuzjastami pomysłu dyrekcji - nie chcieli komplikować i zmieniać wypracowanych metod i procedur nauczania. Mimo że wszyscy nauczyciele brali udział w obowiązkowych szkoleniach organizowanych przez pracowników działu edukacyjnego Apple, z dużą niechęcią przenosili poznane rozwiązania do własnej klasy. Zespół dyrekcyjny zaczął wywierać na nauczycieli presję i zmuszać ich do wykorzystywania tabletów przynajmniej raz w semestrze, obawiając się, że pozostawienie nauczycielom swobody decydowania spowoduje, że w ogólne nie będą z nich korzystać.

\section{Rodzice - kluczowi partnerzy?}

W przypadku obu projektów implementacji tabletów do badanych szkół proces decyzyjny odbywał się z pominięciem rodziców. Nikt ze szkolnych władz nie konsultował się z rodzicami uczniów przed podjęciem ostatecznej decyzji o rozpoczęciu projektu. Zatem, można stwierdzić, że iPady w szkole stały się pretekstem do uważnego przyjrzenia się kwestiom władzy rodziców w szkole, strategiom „pozyskiwania” akceptacji rodziców dla decyzji, które już zapadły oraz strategiom wygaszania ewentualnego "buntu” rodziców w pierwszej fazie realizacji projektów w obu krajach.

Pozycji rodziców w Libii nie można nazwać partnerską względem szkoły, dlatego pomysłodawcy projektu - sektor biznesu - nie zamierzali negocjować go z rodzicami, zwracając się bezpośrednio do dyrektorów szkół. Ci zaś zdefiniowali warunki realizacji projektu, orientując się wyłącznie na szkolne ramy i ich ewentualne zmiany, nie zaś rodziców. Projekt ten ujawnił zatem, że szkoła jest niezależna i w pełni decyduje o jakości pracy pedagogicznej odbywającej się na jej terenie. Pominięcie rodziców jest też w Libii głęboko utrwalone kulturowo: rodzice traktowani są jako ci, którzy „nie wiedzą” czego wymaga prawidłowy rozwój ich dzieci i dlatego w pełni ufają szkole, która „wie lepiej”. Niemniej jednak pomyślna realizacja projektu wymagała edukacyjnego włączenia rodziców na etapie nauki pozaszkolnej, w domu. Był to pierwszy moment, w którym rodzice, zwłaszcza matki, musieli zostać potraktowani jako partnerzy, od decyzji których zależeć będzie sukces projektu. O ile obecność iPadów na terenie szkoły nie została przez rodziców zakwestionowana w najmniejszym stopniu, o tyle ewentualna obecność urządzeń w przestrzeni 
domowej, po zakończonych zajęciach szkolnych budziła większe wątpliwości. Zatem, trzeba stwierdzić, że jednak ujawniły się osobiste teorie pedagogiczne rodziców i obawy rodziców odnośnie tego, co jest edukacyjnie wartościowe dla ich dzieci. Z opcji wypożyczenia iPadów do domu najchętniej korzystały duże rodziny z co najmniej czwórką dzieci. Posiadanie większej liczby dzieci korelowało z większą gotowością do podjęcia ryzyka, eksperymentowania i wypróbowania iPada w domu. Rodzice ci zostali przekonani o korzyściach jakie daje wspólne uczenie się dzieci i tym samym lepszy start dla dzieci najmłodszych, które jeszcze nie rozpoczęły nauki w szkole. Z opcji wypożyczania sprzętu nie korzystały rodziny mniejsze, z dwójką lub trójką dzieci, dla których prawdziwa nauka w domu oznaczała obecność dodatkowego nauczyciela nadzorującego zajęcia pozaszkolne czy odrabianie zadań domowych, a nie tabletu.

Rodzice w swoich wypowiedziach nie odnosili się i nie oceniali tego, co zmienia się w szkole, ale dostrzegli zmiany, jakie dokonują się we wzorach uczenia się ich dzieci w domu. Niemal wszyscy odnotowali, że dzieci spędzają więcej czasu i bardziej angażują się w wykonywanie szkolnych zadań z wykorzystaniem tabletów. Poza tym, często wykonują te zadania wspólnie, angażując najmłodsze dzieci. Dzieci są bardziej zmotywowane do nauki szkolnej, nauka jest dla nich atrakcyjna i emocjonalnie angażująca. Z uwagi na te zmiany rodzice ocenili tablety jako wartościowe narzędzia edukacyjne, z których zamierzają korzystać jak najczęściej. Zaobserwowane zmiany spowodowały, że rodzice uwolnili się od początkowych obaw związanych z technologiami mobilnymi, w tym szczególnie z ryzykiem kontaktu dzieci z nieodpowiednimi treściami dostępnymi w Internecie. Trzeba jednak zaznaczyć, że rodzice nie dokonywali samodzielnego wyboru aplikacji mobilnych dla dzieci, trzymając się wyborów dokonywanych przez nauczycieli.

W przypadku projektu realizowanego w Polsce rodzice również nie zostali włączeni w proces podejmowania decyzji, a jedynie została im ona ogłoszona. Ponieważ wiele dzieci w Polsce jest użytkownikami smartfonów i tabletów, ale nie są one używane w edukacyjnych celach ${ }^{21}$, rodzice nie potrafili sobie wyobrazić, w jaki sposób można wykorzystywać tablety w nauce szkolnej. Wielu rodziców akceptowało decyzję dyrekcji o zakupie iPadów, dostrzegając w niej troskę o unowocześnienie szkoły i uatrakcyjnienie nauki. Niemniej jednak obawy dotyczyły „zabawowych” potencjałów iPadów, które mogłyby wykluczyć poważną naukę w szkole. Obawy te zostały wykluczone argumentami nauczycieli o incydentalnym wykorzystywaniu tabletów i o tym, że nie będą one stałym elementem porządku lekcyjnego. Tym samym, szkoła

${ }^{21}$ Por. H. Bougsiaa i in., Smartfon i tablet w dziecięcych rękach. Być dzieckiem, nastolatkiem i rodzicem w kulturze mobilnej, Gdańsk 2016. 
utwierdziła rodziców w przekonaniu o „zabawowym” charakterze urządzeń mobilnych, o ich funkcji uatrakcyjniania, która jedynie czasami ma przełamać szkolną monotonię. Rodzice otrzymali sprzeczne przekazy głoszące z jednej strony odwagę wprowadzenia pionierskich w tym regionie rozwiązań technologicznych, a z drugiej zapewnienie, że rozwiązania te będą stosowane na tyle rzadko, że nie zmienią i nie zaburzą dotychczasowego porządku. Stwierdzenia te podziałały uspokajająco na większość rodziców. Niemniej jednak kilkoro z nich od samego początku miało do technologii mobilnych stosunek skrajnie negatywny, odmawiając akcepcji i nie wyrażając zgody na udział dzieci $\mathrm{w}$ takich zajęciach. Dyrekcja szkoły zaleciła tym rodzicom spokojne przemyślenie kolejnych kroków związanych z edukacją dziecka, ponieważ decyzja o wykorzystaniu tabletów w szkole jest nieodwracalna i ma zastosowanie do całej uczniowskiej populacji bez wyjątku.

$\mathrm{W}$ trakcie realizacji projektu rodzice zostali zapytani o zaobserwowane zmiany w sposobach uczenia się ich dzieci oraz ocenę owych zmian. Zgodnie podkreślili, że dzieci lubią lekcje z iPadami. Zajęcia te są dla nich atrakcyjne i ciekawe. Niemniej jednak, rodzice nie potrafili wykazać żadnych innych zmian w uczeniu się ich dzieci. Nie dostrzegli też żadnych istotnych różnic w porównaniu z okresem nauki bez iPadów. Ten brak zmian jest, ich zdaniem, spowodowany niezbyt częstym wykorzystaniem sprzętu mobilnego na lekcji. Rodzice mieli zresztą niewielkie pojęcie o tym, jak dokładnie wygląda wykorzystanie iPadów na lekcji i dlatego nie potrafili samodzielnie zainicjować edukacyjnego wykorzystania posiadanych smartfonów i tabletów w domu. Do nielicznych edukacyjnych działań dzieci z wykorzystaniem sprzętu mobilnego dostępnego w domu rodzice zaliczyli: ćwiczenie tabliczki mnożenia (aplikacja), przygotowanie do konkursu z języka angielskiego oparte na aplikacji mobilnej, którą zalecił nauczyciel.

Można zatem stwierdzić, że szkoła ugruntowała przekonania rodziców, że iPad jest zabawką i służy raczej zabawie niż nauce, a jeśli nauce to poprzez zabawę.

\section{Projektowanie edukacyjne szkolnych zajęć}

W tej części zaprezentowane zostaną zarówno wyniki badań wideoetnograficznych, jak i ustalenia pochodzące z wywiadów z nauczycielami, w celu ukazania różnic w sposobach projektowania edukacyjnej pracy na lekcji. Różnice te są spowodowane odmienną kompozycją projektu wdrożenia iPadów do szkoły, ale z drugiej strony - ujawniają też pewną otwartość nauczycieli na nowe rozwiązania, na kwestie uczenia się i wprowadzania zmian do własnego warsztatu pedagogicznego i nabywania nowych umiejętności. 
W projekcie libijskim olbrzymią rolę odgrywali wolontariusze - studenci ICT, którzy służyli nie tylko niezbędnym wsparciem technicznym, ale w praktyce przyjęli na siebie rolę researcherów mobilnych aplikacji, które nadawały się do wykorzystania podczas szkolnych zajęć i odpowiadały potrzebom nauczycieli (ostateczny wybór należał do nauczyciela, który akceptował aplikacje z większej puli wyselekcjonowanych przez researcherów). Wolontariusze byli też obecni na lekcjach, służąc pomocą $\mathrm{w}$ razie wystąpienia problemów technicznych. Wspierali nauczycieli w prowadzeniu zajęć.

$\mathrm{W}$ projekcie polskim nauczyciele po etapie szkolenia musieli radzić sobie sami - zarówno w zakresie preselekcji aplikacji, ich ostatecznego wyboru, jak i rozwiązywania problemów technicznych, które niekiedy pojawiały się podczas pracy na lekcji. Z pewnością są to czynniki, które wyjaśniają zdecydowanie większy opór i nieufność polskich nauczycieli wobec obecności technologii na lekcji. W polskim kontekście zabrakło kompetentnego wsparcia i odpowiedzialnego tutoringu, który otrzymali nauczyciele libijscy.

Nauczyciele w szkołach Trypolisu (w przeważającej większości kobiety), $w$ przeciwieństwie do polskich nauczycielek wczesnej edukacji, entuzjastycznie przyjęli pomysł wprowadzenia technologii mobilnych do szkoły. Projekt potraktowany został z otwartością i deklarowaną chęcią zdobycia praktycznych umiejętności projektowania zajęć lekcyjnych z użyciem nowej technologii. Nie odnotowano problemów opisywanych w literaturze przedmiotu o oporze nauczycieli w krajach arabskich i ich strachu przed zachodnimi technologiami. Jedyną obawą nauczycieli była kwestia zachowania dyscypliny, bowiem w libijskich szkołach surowa dyscyplina, ze stosowaniem kar fizycznych włącznie, stanowi podstawę oddziaływań dydaktyczno-wychowawczych. Zaproponowany nauczycielom model pracy grupowej, rearanżacja przestrzeni klasy szkolnej w kierunku rozwiązań sprzyjających pracy małych grup okazała się dla niektórych nauczycieli trudnym doświadczeniem edukacyjnym. Niemniej jednak taki układ wspólnotowego uczenia się okazał się korzystny dla nauczycieli, którzy - zgodnie z beduińską pedagogią - zmuszeni są do ciągłego opowiadania historii adekwatnej do nauczanych treści i skupiania na sobie dziecięcej uwagi. Mobilne aplikacje do nauki języka arabskiego czy edukacji społeczno-przyrodniczej uwolniły nauczycieli z tego obowiązku, co odczytali jako korzystną zmianę.

Z wywiadów z nauczycielami uczącymi w polskiej szkole wynikało, że nie byli oni do końca przekonani o sensowności pracy z wykorzystaniem mobilnych technologii. Obawiali się, że angażujące i atrakcyjne "gadżety" przesłonią przekaz wiedzy i, wbrew oczekiwaniom, dzieci będą osiągać gorsze wyniki w nauce.

Niemniej różnice nastawień i oczekiwań nauczycieli polskich i libijskich do projektu, różnice w zakresie zewnętrznego wsparcia nie wyjaśniają prze- 
konująco bardzo znaczących odmienności w edukacyjnym projektowaniu lekcji, kompozycji mobilnych aplikacji i sposobach realizowania celów zajęć.

Różnice w korzystaniu z aplikacji mobilnych

Tabela 1

\begin{tabular}{|l|c|c|}
\hline \multicolumn{1}{|c|}{ Typ aplikacji/typ działań } & Szkoła libijska & Szkoła polska \\
\hline Interaktywne książki & 15 & 0 \\
\hline Aplikacje do tworzenia książek & 10 & 1 \\
\hline Storytelling & 13 & 0 \\
\hline Kaligrafia, rozpoznawanie liter & 12 & 3 \\
\hline $\begin{array}{l}\text { Aplikacje matematyczne } \\
\text { (podstawowe działania: dodawanie, odejmowanie, } \\
\text { mnożenie, dzielenie) }\end{array}$ & 11 & 10 \\
\hline Aplikacje do nauki języka angielskiego & 9 & 9 \\
\hline $\begin{array}{l}\text { Aplikacje artystyczne (muzeum, rysowanie, two- } \\
\text { rzenie kolaży) }\end{array}$ & 6 & 11 \\
\hline Aplikacje społeczno-przyrodnicze (puzzle, quizy) & 7 & 2 \\
\hline Aplikacje do nauki religii & 3 & 1 \\
\hline Safari (przeglądarka internetowa) & 0 & 8 \\
\hline
\end{tabular}

Źródło: badania własne (materiał wideoetnograficzny).

Polscy nauczyciele, w przeciwieństwie do libijskich, nie korzystali z aplikacji służących stymulowaniu umiejętności czytania, pisania i opowiadania historii przez dzieci. W dużo większym stopniu korzystali z aplikacji mobilnych zawierających zestawy ćwiczeń z dużą liczbą powtórzeń - na przykład tabliczka mnożenia, tworzenie obrazka z gotowych elementów, nauka słówek w języku angielskim. Były to zazwyczaj zadania ćwiczące konkretne umiejętności, bazujące na spostrzegawczości, szybkiej reakcji i umiejętności odtworzenia zapamiętanych treści. Nauczyciele polscy dopuszczali też, w dużo większym stopniu niż nauczyciele libijscy, korzystanie z Internetu w poszukiwaniu rozwiązań szkolnych zadań.

Z wywiadów z nauczycielami libijskimi wynikało, że starają się oni korzystać z iPadów jako otwartych narzędzi edukacyjnych, które zapewniają dzieciom to, czego nie dają podręcznik i ćwiczenia, stąd ich preferencje skierowane są ku interaktywności urządzenia - możliwości nagrania opowiadanej historii, nagrania poprawności czytania. Zdaniem nauczycieli, aplikacje te angażują wiele różnorodnych umiejętności, dlatego należą do najbardziej wartościowych. 
Z kolei polscy nauczyciele skarżyli się na brak czasu na poszukiwanie aplikacji odpowiednich do wykorzystania na lekcji oraz brak aplikacji, które byłyby w pełni zgodne z materiałem podręcznikowym lub zawartym w zeszycie ćwiczeń. Optymalna byłaby dla nich sytuacja, w której wydawcy tradycyjnych materiałów dydaktycznych przygotowywaliby również zestaw aplikacji mobilnych, które stanowiłyby ich uzupełnienie lub rozszerzenie. Jest to ustalenie niepokojące, świadczące o orientacji, że nauczanie rozumiane jest jako przekazywanie treści podręcznika i braku samodzielności w dobieraniu materiałów dydaktycznych. Ustalenie to wskazuje również, że podręcznik jest wciąż traktowany jako dominujące źródło wiedzy, któremu inne źródła muszą być ściśle podporządkowane.

Z wyboru aplikacji mobilnych przez polskich nauczycieli „wyczytać” można rolę, jaką miały pełnić w kształceniu dzieci - rolę uzupełniającą, ilustracyjną, relaksującą, ale nie wiodącą podczas zajęć. Nauczycielskie preferencje w zakresie aplikacji związane były raczej z kontrolą poprawności ćwiczeń, wielością ćwiczeń i dostarczaniem informacji o poziomie wykonania zadań (po wykonanych ćwiczeniach wyświetla się statystyka - błędów i poprawnych odpowiedzi). Nauczyciele z polskiej szkoły raczej niechętnie korzystali z aplikacji, w których zakłada się samodzielną, swobodną ekspresję uczniowską.

W obu analizowanych przypadkach nie odnotowano, by nauczyciele wczesnej edukacji w jakikolwiek sposób odwoływali się do technik wideo (aplikacji) w pracy dzieci na lekcjach.

\section{Nauczyciele o zmianach we wzorach dziecięcego uczenia się}

Nauczyciele libijscy biorący udział w projekcie dostrzegli mnóstwo zmian związanych z funkcjonowaniem uczniów na lekcjach. Do najważniejszych kwestii zaliczyli: większe zainteresowanie przedmiotem, entuzjastyczne i w pełni zaangażowane uczenie się. W opinii nauczycieli, dzieci nauczyły się większej samodzielności i podejmowania decyzji dotyczących sposobu realizacji otrzymanych zadań. Zdecydowanie częściej podejmowały też współpracę w grupie, przejawiały inicjatywę. Zdaniem nauczycieli, iPady w klasie szkolnej okazały się dla dzieci doświadczeniem emancypacyjnym, polegającym na „rozpuszczeniu” dotychczasowych hierarchii i barier. Nowe narzędzie edukacyjne dało dzieciom prawo do aktywności, zadawania pytań, eksperymentowania i samodzielnego regulowania własnego uczenia się, dzięki czemu straciły poczucie bycia w szkole, w której podlegały nieustannej presji i dominacji ze strony nauczycieli. iPady w szkole dały dzieciom możliwość 
uczenia się w warunkach wolności i bez przymusu. Jedno ze stwierdzeń nauczycieli dobrze podsumowuje tę emancypacyjną zmianę: „widzieliśmy, że dzieci są w szkole po prostu szczęśliwe".

Zmiany dotyczyły też sposobu pracy nauczycieli, którzy - jak twierdzą nauczyli się organizowania i wyzwalania uczniowskiej aktywności, dobrego planowania i zarządzania czasem oraz innego stylu komunikacji z uczniami, którego istotą jest doradzanie i konsultowanie, zamiast dyrektywnego kierowania pracą.

Nauczyciele w Polsce zauważyli, iż zajęcia podczas których wykorzystywane były iPady stały się dla dzieci zdecydowanie bardziej interesujące niż zajęcia tradycyjne, że dzieci chętnej angażowały się w pracę, że były „aż za bardzo" samodzielne i pracowały „za szybko". Polskich nauczycieli niepokoiła też swoista "przewaga technologiczna” dzieci, ich zdolność intuicyjnego wykrywania nowych, nieznanych nauczycielom funkcjonalności urządzeń, ich możliwości, aplikacji, która im samym nie była dana. Ta przewaga sprawiała, że nauczyciele mieli trudności w kontrolowaniu klasy i panowaniu nad całokształtem dziecięcej aktywności. Analiza materiału wideo w pełni potwierdza te przekonania. Nauczyciele starali się bowiem podporządkować to nowe narzędzie dominującemu porządkowi transmisyjnej szkoły. Dzieci musiały pracować samodzielnie (w modelu 1 dziecko - 1 iPad), wykonując te same zadania, w tym samym czasie i tym samym tempie. Komunikację nauczycieli z uczniami budowały w znakomitej większości stwierdzenia o charakterze instruktażu. Doradzanie i zachęcanie do samodzielnej pracy zdarzały się niezbyt często.

W analizowanych materiałach wideo niewiele miejsca zajmowała też praca grupowa. Niemniej jednak, uczniowie pracując w pojedynkę, przekraczali to ograniczenie, komunikując efekty swojej pracy koleżankom i kolegom. Przymus pracy w tym samym tempie powodował, że dzieci pracujące szybciej miały sporo wolnego czasu, który był poświęcany na poznawanie innych możliwości iPada (korzystanie z innych aplikacji), co z kolei nauczyciele odbierali jako przejawy uczniowskiej niesubordynacji i argument przeciw częstszemu korzystaniu z tabletów na lekcjach.

Zdaniem badanych nauczycieli, nauka szkolna nie musi być ciekawa, a uczeń nie musi być w nią bardzo zaangażowany. Znacznie istotniejsze dla sukcesu szkolnego uczniów jest, zdaniem badanych, podporządkowanie się nauczycielowi. Uczniowie, $\mathrm{w}$ ich opinii, mają problemy z zachowaniem dyscypliny i niechętnie się podporządkowują, a iPady jedynie te problemy pogłębiają. Badani nauczyciele deklarowali zrozumienie dla potrzeby kształcenia uwzględniającego nowe narzędzia informatyczne, ale, zdaniem badanych, polska szkoła jest na nie nieprzygotowana. Nauczyciele, 
zdaniem badanych, nie mają czasu, aby się nauczyć nowych rozwiązań, nie mają umiejętności i są zbyt pochłonięci realizacją programu nauczania i sprawdzaniem wiedzy.

\section{Dzieci i iPady: \\ radość uczenia się poza kontrolą nauczycieli?}

Z danych wideo i rozmów z dziećmi ze szkoły polskiej i libijskiej wyłania się obraz pełen podobieństw. Podczas zajęć z wykorzystaniem iPadów uczniowie wykazywali się dużą aktywnością, byli bardzo zaangażowani i skoncentrowani na wykonaniu zadań. Kontakt z urządzeniem sprawiał im wielką przyjemność, którą usiłowali przedłużyć, często negocjując z nauczycielami możliwość wykonania zadań dodatkowych. Dzieci wykazywały się inicjatywą, chętnie pomagały kolegom i dzieliły się pomysłami. Z zapisów wideo wynika, że w tym okresie rozwojowym (8-9 lat) bardzo stresuje je presja czasowa (np. zadania matematyczne, w których liczy się poprawność rozwiązań wykonanych w określonym czasie) oraz rywalizacja grupowa, którą czasami stosowali nauczyciele. Dzieci zdecydowanie lepiej radziły sobie z zadaniami tego typu, kiedy odkryły, że licznik czasu można samodzielnie wyłączyć.

Dzieci zdecydowanie najlepiej funkcjonowały w trybie współpracy grupowej. Jeśli nauczyciel nie inicjował takiej formy pracy na konkretnych zajęciach, same organizowały grupy wokół siebie. Grupa zapewniała im bowiem nie tylko wsparcie, ale była źródłem alternatywnych pomysłów, rozwiązań, innych umiejętności itp., co powodowało, że praca z iPadem oferowała im zawsze pulę nowych doświadczeń i ekscytujących odkryć. Grupa stała się zatem miejscem autentycznego synergicznego uczenia się i komunikacji, dzięki którym dzieci intuicyjnie wykraczały poza już posiadane umiejętności czy wiedzę 22 .

Warto również podkreślić, że podczas prac grupowych często można było zauważyć, że dzieci wykonywały jednocześnie wiele zadań. Całkowicie spontanicznie organizowały uczenie się tak, by posiadany sprzęt wykorzystywać w alternatywny sposób, w różnych kontekstach, co interpretujemy jako tworzenie sytuacji wieloźródłowości wiedzy. W kulturowo konserwatywnych szkołach, w których dzieci są poznawczo uzależnione od autorytetu dorosłych i przyuczane, że podręcznik jest jedynym źródłem

${ }^{22}$ Aktywne dzieci i intuicyjna technologia tworzą interesujący edukacyjny asemblaż, który jest nieznany w tradycyjnej szkole. Por. D. Klus-Stańska, Prazo dzieci do myślenia - obszar w szkole nieznany, Szkice Humanistyczne, 2010, 10, 2-3, s. 245-253. 
„prawdziwej” wiedzy, tablety sprzyjały demokratyzacji uczenia się i paradoksalnie przywracały dzieciom podmiotowość jako kompetentnym twórcom wiedzy.

\section{Dyskusja i wnioski końcowe}

Celem niniejszych badań było opisanie efektów projektu wdrożenia nowych rozwiązań technologicznych w pracy szkół na etapie wczesnej edukacji. Naszą intencją nie było mierzenie i porównanie wyników kształcenia, nie chodziło o kontekst poprawy efektywności nauczania. Chodziło raczej o ukazanie, czy "czarny ekran” jako nowy edukacyjny aktor wyzwala jakieś zmiany $w$ istniejących strukturach i kulturze edukacji. Rzecz jasna, tablety nie są same z siebie sprawcze. Stają się sprawcze jako elementy edukacyjnej kultury, kiedy wymuszają na całej szkolnej społeczności aktywność, uczenie się oraz wypracowanie miejsca i roli technologii mobilnych w szkolnym środowisku. Jako nowe elementy szkolnej rzeczywistości technologie mobilne miały zdolność wydobywania na światło dzienne i kwestionowania rozmaitych oczywistych konstrukcji: władzy nauczyciela w klasie, przekonania o prawomocnych źródłach wiedzy, o optymalnej organizacji uczenia się, o tym w jakich warunkach ono zachodzi.

Sposób wdrażania iPadów w obu analizowanych szkołach wskazał niezbicie, że rodzice są ignorowanymi podmiotami szkolnej rzeczywistości $\mathrm{w}$ aspekcie podejmowania kluczowych decyzji, a jednocześnie istotnym podmiotem z punktu widzenia możliwości realizowania projektów zgodnie z przyjętymi założeniami. Na przykład, w Libii rodzice okazali się kluczowym podmiotem dla możliwości konstruowania przez szkołę zrębów kultury edukacyjnej w domu i promocji prawdziwie edukacyjnego wykorzystywania narzędzi mobilnych. Z kolei w Polsce sceptycyzm rodziców okazał się "dobrym uzasadnieniem" dla oporowych działań nauczycieli i ich niewielkiego zaangażowania w pracę z wykorzystaniem nowych technologii.

Istotnym aspektem przesądzającym o pełnym sukcesie projektu w libijskiej szkole i jedynie częściowym sukcesie projektu w szkole polskiej była niewątpliwie kwestia codziennego, merytorycznego wsparcia udzielanego nauczycielom przez tutorów w uczeniu się możliwości nowego narzędzia edukacyjnego. Jednorazowe szkolenie dla nauczycieli z udziałem profesjonalistów - szkoleniowców nie było wystarczającym wsparciem. Większą efektywność osiągnięto dzięki codziennemu wspieraniu nauczycieli przez studentów ICT (których nie można nazwać w pełni profesjonalną kadrą), na szkolnym terenie, w konkretnej pracy nauczycieli, w rzeczywistych szkolnych sytuacjach. Dzięki temu swoistemu tutoringowi nauczyciele libijscy 
mieli szansę przyjrzenia się, w jakich warunkach, z jakim zaangażowaniem osiąga się optymalne rezultaty z punktu widzenia dzieci. W przypadku nauczycieli w szkołach polskich wymagania te odsłoniły się dopiero podczas pierwszych, samodzielnych prób wykorzystania iPadów na zajęciach lekcyjnych. Odkrycia te nie zachęcały nauczycieli do podejmowania dalszych, czasochłonnych poszukiwań.

Projekty realizowane w obu krajach ujawniły również zróżnicowaną gotowość nauczycieli do uczenia się nowych rzeczy i podejmowania wyzwań z myślą o dobru dzieci. Gotowość ta była wyższa w szkole libijskiej niż polskiej, w której nauczyciele niechętnie modyfikują repertuar metod pracy, dobrze odnajdują się w rutynie, z której czerpią przekonanie o własnej kompetencji. Tę niegotowość potwierdzają zresztą liczne badania poświęcone polskiej wczesnej edukacji ${ }^{23}$.

Projekty wprowadzania tabletów do badanych szkół ujawniły również sprzeczność interesów dyrekcji - które próbowały nadać projektom określoną definicję i ramy: powolne zmiany filozofii kształcenia w libijskiej szkole i liderską pozycję innowacyjnej szkoły w Polsce - oraz nauczycieli zatrudnionych w tych szkołach. To nauczyciele spowodowali, że - w kontekście libijskim - zmiana dokonała się bardzo szybko (wbrew woli dyrekcji), a w kontekście polskim trudno dopatrywać się jakiejkolwiek innowacyjności, gdyż tablety zostały odsunięte na margines i były wykorzystywane w minimalnym zakresie.

Najistotniejszym podmiotem tych projektów były dzieci, z myślą o których szkoły wykonały tak znaczący i kosztowny ruch modernizacyjny. Wydaje się, że w obu badanych kontekstach dzieci optymalnie wykorzystały sposobność uczenia się oferowanego przez nowoczesne narzędzia, w ramach narzuconych przez ich nauczycieli. Potencjał wspólnotowego uczenia się był w tym przypadku nie do przecenienia, zwłaszcza w zakresie tak zwanych miękkich umiejętności (praca w grupie, dzielenie się, inicjatywa, liderstwo, umiejętność podejmowania różnych ról w grupie, komunikowanie pomysłów, ocenianie ich wartości).

Nie mamy wątpliwości, że narzędzia mobilne można z powodzeniem nazwać narzędziami konwiwialnymi w edukacji ${ }^{24}$, czyli takimi, którymi mogą posłużyć się jednostki, by nawiązać między sobą komunikację i organizować swoje wysiłki na drodze realizowania osobistych celów życiowych. Narzędzia te ułatwiają życie konwiwialne (wspólne z innymi) w tym zakresie, w jakim mogą być używane z łatwością przez kogokolwiek, tak często lub tak

${ }^{23}$ H. Kwiatkowska, Tożsamość nauczycieli - między anomia a autonomia, Gdańsk 2005; taże, Nowy nauczyciel na czas globalizacji i nowoczesnych technologii, Nowe Horyzonty Edukacji, 2014, 3, s. 39-47.

${ }^{24}$ I. Illich, Tools for Conviviality, New York 1973. 
rzadko jak trzeba, z myślą o osiągnięciu celu wybranego przez użytkownika. W tym kontekście bazą jest, naszym zdaniem, dziecięce, wspólnotowe uczenie się, które dokonuje się wbrew szkole i niejako w opozycji do określonych przez nią ram. Warto podjąć ten interesujący wątek w dalszych badaniach nad obecnością technologii mobilnych w szkołach i zdecydowanie dokładniej określić jego znaczenie $\mathrm{w}$ dziecięcym uczeniu się.

Rzecz jasna, wyniki zrelacjonowanych badań nie mogą być uogólniane i ekstrapolowane na inne szkoły i inne uczące się społeczności. Niemniej jednak warto podejmować badania nad oddolnymi inicjatywami edukacyjnymi, w świetle których można opisać dynamikę zmian i wyzwania, jakie generuje pojawienie się mobilnych technologii w niemobilnych szkolnych układach. W tych lokalnych kontekstach i dzięki takim oddolnym inicjatywom kształtują się bowiem kompetencje cyfrowe dzieci i podstawy ich partycypacji w zglobalizowanej kulturze cyfrowej.

\section{BIBLIOGRAFIA}

Bougsiaa H., Cackowska M., Kopciewicz L., Nowicki T., Smartfon i tablet $w$ dziecięcych rękach. Być dzieckiem, nastolatkiem i rodzicem w kulturze mobilnej, Wydawnictwo Naukowe Katedra, Gdańsk 2016.

Buckingham D., Beyond technology: children's learning in the age of digital culture, Polity Press, Cambridge, 2007.

Buckingham D., Nowe media - nowe postaci dzieciństwa? Zmieniające się środowisko kulturowe dzieci w erze technologii cyfrowej, [w:] Wprowadzenie do badań nad dziecinstwem, red. M.J. Kehily, Wydawnictwo WAM, Kraków 2008.

Caron A.H., Caronia L., Moving cultures. Mobile communication in everyday life, McGill-Queens University Press, Montreal 2007.

Clark N., Education in Libya, ,World Education News and Reviews, 2004, 17(4), http:/ /www. wes.org/eWENR/04July/Practical.htm; [dostęp: 28.07.2017].

Derry S.J., Pea R.D., Barron B., Engle R.A., Erickson F., Goldman R., Hall R., Koschmann T., Lemke J.L., Gamon Sherin M., Sherin B.L., Conducting Video Research in the Learning Sciences: Guidance on Selection, Analysis, Technology, and Ethics, Journal of the Learning Sciences, 2010, 19, 1.

Dingli A., Seychel D., The New Digital Natives: Cutting the Chord, Springer-Verlag, Berlin Heidelberg 2015.

Dylak S., Architektura wiedzy w szkole, Wydawnictwo Difin, Warszawa 2013.

Gasparini A., Culén L.A., Children's Journey with iPads in the Classroom. Opportunities and Challenges when Designing and Developing with Kids @ School, [w:] Interaction Design for Children Conference (IDC 2011), Ann Arbor, Michigan 2011.

Hamdy A., ICT in education in Libya. Libya Country Report, http:/ /www.infodev.org/en/ Document.412.pdf [dostęp: 23 czerwca 2017].

Illich I., Tools for Conviviality, Harper and Row, New York 1973.

Klus-Stańska D., Poza kulturę nadzoru : eksperymentowanie w szkole i ze szkoła : z profesor Dorota Klus-Stańskq rozmawia mgr Sylwester Zielka, Ars Educandi, 2010, 7. 
Klus-Stańska D., Prawo dzieci do myślenia - obszar w szkole nieznany, Szkice Humanistyczne, 2010, 10, 2-3.

Klus-Stańska D., Nauczanie początkowe jako wczesny trening do marginalizacji. Kontrowersyjność społecznej wiedzy szkolnej, Forum Oświatowe, 2011, 1(44).

Kwiatkowska H., Nowy nauczyciel na czas globalizacji i nowoczesnych technologii, Nowe Horyzonty Edukacji, 20014, 3.

Kwiatkowska H., Tożsamość nauczycieli - między anomia a autonomią, Gdańskie Wydawnictwo Psychologiczne, Gdańsk 2005.

Mendyk M., Wspótpraca z rodzicami z perspektywy nauczycieli edukacji wczesnoszkolnej - raport z badań, [w:] Codzienność szkoły - nauczyciel, red. J.M. Łukasik, I. Nowosad, M.J. Szymański, Oficyna Wydawnicza Impuls, Kraków 2014.

Nosol P., Technologia $i$ sport, Wydawnictwo Naukowe Katedra, Gdańsk 2014.

Nowicki T., Technologiczne transpozycje podmiotu i pracy, Teraźniejszość - Człowiek - Edukacja, 2016, 19, 2(74).

Pegrum M., Mobile learning. Languages, literacies, cultures, Palgrave Macmillan, New York 2014.

Traxler J., Education and the Impact of Mobiles and Mobility: An Introduction to Mobiles in our Societies, [w:] Medienbildung in neuen Kulturraumen: Die deutchsprachige und britische Diskussion, red. B. Bachmair, VS Verlang fur Sozialwissenschaften, Wiesbaden 2010.

Traxler J., Will Student Devices Deliver Innovation, Inclusion E Transformation? Journal of the Research Center for Educational Technology at Kent State University, 2010, 6, 1.

Traxler J., Mobile learning. Starting in the right place, going in the right direction? [w:] Innovations in Mobile Educational Technologies and Applications, red. D. Parsons, ISR, Hershey 2013.

Winiarski M., Relacje rodzina - szkoła w perspektywie wspótpracy, [w:] Pedagogika społeczna wobec zagrożeń człowieka i idei sprawiedliwości społecznej, red. W. Danilewicz, W. Theiss, Wydawnictwo Akademickie Żak, Warszawa 2014. 